\title{
Multicultural Education Past, Present, and Future: Struggles for Dialog and Power-Sharing
}

\author{
Christine Sleeter \\ California State University Monterey Bay \\ U. S. A.
}

ABSTRACT: Using Kymlicka's analysis of conflicts between "imperatives of state control" and "objectives of social movements," I draw on my experiences with multicultural education to extrapolate some trends from the past and present that may inform the future. After briefly describing the origins of multicultural education (mainly within the United States), I situate struggles over education in the context of the global expansion of neoliberalism, critique "neoliberal multicultural education," then briefly describe some efforts that push back. This essay concludes with four recommendations for moving forward.

KEYWORDS: multicultural education, neoliberalism, dialog, power-sharing, intercultural education

Multicultural Education Comes into Being Twenty-Two Years and Two Emblematic Experiences Ago Elites React Neoliberal Multicultural Education?

Countermovements Looking Ahead References Author Contact

The year was 1974. I was seated in an auditorium along with many other Seattle Public Schools teachers, participating in what we would now call a multicultural education workshop. The term "multicultural education" had appeared in print in the United States only a year earlier when the American Association of Colleges of Teacher Education issued its report No One Model American: A Statement on Multicultural Education (Commission on Multicultural Education, 1973). While the great majority of teachers in the auditorium were White, the team leading the workshop was racially and ethnically diverse. Its founder, a Japanese American woman, had been imprisoned as a child in U.S. internment camps during World War II. What struck me was that the team included two White facilitators, but they did not dominate its work. I glimpsed my future.

When I think about multicultural education, this image often comes into my mind because it represents a shift in who has the power to define the problems, the issues, the work, and the purpose of that work. Within any nation, learning to share power in the context of a history of relationships of dominance and 
subordination is necessary but extremely difficult. At a global level, an additional challenge is that the field of multicultural education is dominated by U.S. perspectives. As I reflect on my own past and present experiences with multicultural education, these are issues that surface.

In this essay, I argue that multicultural education is more than a set of strategies or curriculum content, although it certainly includes these. It is also a site of struggle for the power to define the purposes and processes of education in a diverse and unequal world. To discuss this struggle, I will draw on Kymlicka's (2013) analysis of conflict between "imperatives of state control" and "objectives of social movements" (p. 102). Buffeted by that conflict, multicultural education, which grew out of social movements, has both defined and been defined by attempts by dominant social groups to maintain control, a struggle reflected in the past, the present, and undoubtedly the future.

\section{Multicultural Education Comes into Being}

In the United States, as schools were desegregated during the 1960s and 1970s, students of color (minoritized students) experienced various forms of racism in what had been all-White schools, prompting workshops like the one I participated in. African Americans began to collaborate with other racially marginalized and colonized groups (including Mexican Americans, Puerto Ricans, Asian Americans, and American Indians) to envision and advocate for inclusive school practices on levels ranging from curriculum, to teacher expectations of learning, to home-school relationships. Banks (1996) explains that multi-ethnic education became multicultural education as "other groups who considered themselves on the margins of society [particularly women and people with disabilities] began to demand that the school curriculum - and later other aspects of the school-be changed" (p. 40).

Multicultural education was taken up in several other countries as well, its meaning always involving struggle between people of color and Whites. Canada, for example, adopted a national Multicultural Policy in 1971. Designed to complement the 1969 Official Languages Act, that policy subsumed multiculturalism within an English-French bilingual framework. In the United Kingdom, multiculturalism in national policy was directed toward assimilating immigrants from its former colonies by emphasizing shared culture and values as well as appreciation of cultural differences. In both countries, minoritized people experiencing racial discrimination countered (along with some White allies) with anti-racist education as a much more potent alternative because of its emphasis on racism as the core problem (Dei, 1993; Troyna, 1987).

Kymlicka (2013) points out that increasingly throughout Western nations minority rights were fought for and gradually recognized and, as a result, laws and practices began to be instantiated which went beyond ensuring non-discrimination and cultural appreciation. He gives the example of Aboriginal peoples in Canada 
gaining voting rights during the 1960s, following from a logic of non-discrimination, then later the power of self-government in the 1980s, following a logic of recognizing collective community and cultural rights. Through the 1970s and 1980s, multicultural education was developed extensively at a theoretical level (especially in the United States) in the direction of collective and cultural rights. Gay (1983) described the 1970s as "prime times" for multicultural education, "an era of growth and expansion, both quantitative and qualitative" (p. 562). Expansion included not only curriculum and pedagogy for racially and ethnically diverse students, but also culture-centered work such as revitalizing American Indian cultures and languages (McCarty, 1993), expanding Black independent schools (Ratteray, 1990), and building pedagogy on learning processes students bring from home (Au \& Jordan, 1981).

But since most teachers were (and still are) White, considerable effort was expended trying to engage them in the basics of multicultural education, and I would venture to say that such efforts inadvertently diluted how many people understood multicultural education. For example, Carl Grant and I conceptualized five approaches to multicultural education based partially on how we heard teachers we were working with describe it (Sleeter \& Grant, 2009). While our intent was to stretch and complicate the meanings teachers attributed to multicultural education, many seemed to regard our lower level approaches - especially Human Relations or cross-cultural appreciation-as providing a vocabulary and rationale for what they were already doing. By 1995, Gay observed that the theoretical development of multicultural education "is far out-stripping its practical development" (p. 4). Seeing a growing chasm between theoretical articulations and classroom practice, she urged multicultural education theorists to give much more attention to educators' developmental processes in learning to work with multicultural education in its complexity.

Despite these challenges, I entered the 1990s with a sense of purpose and optimism. Multicultural education was being taken seriously. In the United States, it had its own national organization (the National Association for Multicultural Education was founded in 1990), as well as various state organizations and journals dedicated to its work. Teacher education programs increasingly advertised faculty positions in multicultural education. Many schools seemed to be reaching their students of color better, partially as a result of these efforts, as evidenced by jumps in scores on the National Assessment of Education Progress for African American and Latino students. And recognition of multiple forms of oppression was growing and becoming a part of multicultural education. For example, disability rights offered an alternative discourse to the medical model of special education (e.g., Linton, 1998), and heteronormativity in schooling was being challenged (e.g., MacGillivray, 2000).

\section{Twenty-Two Years and Two Emblematic Experiences Ago}

In 1995, I was afforded two opportunities that pushed my thinking about 
multicultural education: a consulting trip to South Africa and a position helping to found a new university.

In July, I spent three weeks in post-apartheid South Africa. I had been invited because my writings (with Carl Grant) about models of multicultural education and implications for work in the classroom had become quite well known. White South Africans who invited me believed South Africa should adopt one of our models, skipping over the potential conflict and chaos of trying to invent their own. I quickly realized, however, that a huge problem facing South Africa was that many White people took for granted the right to define problems and solutions, and many had never learned to listen to, dialog with, or collaborate with Black South Africans. While I dutifully led workshops on models of multicultural education, I spent much of the three weeks talking with White South Africans about my own experiences learning to hear people of color within the United States and to co-construct analyses of problems and solutions alongside them. In my mind's eye, I kept seeing the White facilitators in that 1974 workshop who had learned to work with, rather than dominate, their colleagues of color. My intent was to prod my White South African hosts away from suggesting to other South Africans how to reconstruct education, and toward listening to and collaborating with Black South Africans. I do not know the extent to which that happened. But I returned home very clear that multicultural education first and foremost involves building relationships of reciprocity and dialog. Classroom practices should follow from dialog rather than substitute for it. I also returned with an appreciation for the problem of U.S. hegemony in multicultural education. While national experiences and insights can be shared through dialog, they cannot be simply transported.

The second opportunity came about as a result of being hired as a founding faculty member at California State University Monterey Bay (CSUMB). I was drawn by its vision of "serving the diverse people of California, especially the working class and historically undereducated and low-income populations," through a program "framed by substantive commitment to multilingual, multicultural, genderequitable learning" (https://csumb.edu/about/founding-vision-statement). For the first few years, about half of the faculty were people of color, most of whom brought commitment to building an institution on principles of multicultural education (understood in varied ways). Despite huge planning challenges (such as far too little planning time before the arrival of the first students, and being located within a highly bureaucratic university system), I shared with most other faculty members the sheer excitement of being on the ground floor of a new institution founded on a progressive vision for educating a highly diverse student population.

The most energizing role I played was directing the development of the Master of Arts in Education program (Sleeter et al., 2005). I brought together a racially and ethnically diverse group of faculty members to conceptualize the program and teach in it. Collaboratively, we built every course around social justice and multicultural education, and we worked together to support the academic success of the widely diverse educators who enrolled in the program. The collaborative power-sharing I remembered seeing in 1974 appeared to work! I felt as though I had learned to drive the new vehicle that was the wave of the future. 


\section{Elites React}

In fall 1999, a conversation in class prompted me to realize that the wave of the future was already moving in an entirely different direction. I was teaching a graduate course, Multicultural Curriculum Design. While analyzing the ideology embodied in teachers' curricula-for example, distinguishing between education for domestication versus liberation (Freire, 1972) - and considering social movements of the 1960s, a Mexican American bilingual education teacher expressed frustration. She was teaching in a low-income middle school that served mainly Mexican American students, and she was having difficulty seeing how the Chicano movement of the 1960s and 1970s led to improvements in the lives of her students today. She went on to say that, while the issues we were discussing in class-issues such as sociocultural representation in textbooks and what liberatory practice might look like in the classroom-were personally interesting to her, no one in her school was talking about these things at all. Instead, discussions focused entirely on aligning the curriculum with the new state standards and tests.

Standards-based school reform had driven CSUMB faculty members' discussions with local school administrators since I arrived. Initially, I interpreted these discussions as indicating the predominantly White administrators' lack of familiarity with multicultural education, an interpretation confirmed when one of them commented that it addresses classroom climate but not curriculum and pedagogy. But it was not until this Mexican American bilingual education teacher, whom I had known for about a year, turned her attention away from multicultural education and its roots in social movements, and toward standards-based reform, that I sensed a sea change in process.

Seeds of standards-based reform in the United States had actually been planted about 15 years earlier, beginning with publication of $A$ Nation at Risk (National Commission on Excellence in Education, 1983). That publication launched highly visible national discussions that framed the main purpose of schools, not as preparing children and youth for a diverse democracy, but rather as regaining U.S. international competitive advantage. Schools were charged with failing to teach students the skills and knowledge needed for global economic competition. In addition, conservative think tanks produced a rash of highly visible, highly negative critiques of multiculturalism in the United States (Sleeter, 1995). The education crisis portrayed in these reports framed multiculturalism as unjustified demands of "special interests" and called for accountability-based solutions: setting explicit standards, aligning resources to those standards, and measuring the extent to which they are met. In response, states began to construct fairly traditional disciplinary content standards and testing programs. By the fall of 1999, every state had developed content standards and tests aligned to them. Teaching to the new content standards and tests was now the focus of teacher professional development. 
School reform has always been part of the business agenda to shape social institutions, generally in accordance with the perspectives and desires of the wealthiest elite. By the end of World War I, the wealthiest $0.1 \%$ of the U.S. population controlled about $5-10 \%$ of the national income; similar data are available for other countries such as the United Kingdom and France. But their share declined sharply during the Great Depression. New Deal programs in the United States, such as emergency job relief, public works programs, social security, progressive and inheritance taxation, and corporate regulations, lowered the top $0.1 \%$ 's proportion of the national income to about $2 \%$ (Harvey, 2005).

So, immediately following World War II, a small group of economic conservatives, joined later by wealthy corporate leaders, articulated a set of principles maintaining that society flourishes and the economy is most robust when built on the principles of individual liberty, private property, and market competition. These principles became known as neoliberalism. Around 1970, coinciding with the multicultural movements, this coalition of wealthy business owners and intellectual conservatives developed strategies to roll back government regulations on the economy (Mayer, 2016), strategies first field-tested on a large scale in Chile under the dictator Pinochet (Torres, 2002). In the United States, starting in 1978, Congress began passing deep tax cuts (Hacker \& Pierson, 2010), launching economic reforms that publications like $A$ Nation at Risk (National Commission on Excellence in Education, 1983) were convincing the U.S. public to support. As a result of neoliberal economic reforms, by 1988 the share of national income of the wealthiest $0.1 \%$ had jumped up to about $5 \%$ (Harvey, 2005).

This blueprint for social and economic reform went global. While globalization refers simply to increased movement of people, goods, and ideas across borders, the wealthiest corporations, using tools such as the World Trade Organization and the International Monetary Fund, structured who decides what is moved across which borders, under what conditions, at what cost, and implicitly for whose benefit. In essence, private corporations and their investors now controlled the levers of the global economy (Neilsen, 2011), and began reshaping other institutions, including education. Writing from the vantage point of Spain, Aguado-Odina, Mata-Benito, and Gil-Juarena (2017) describe effects of this neoliberal world as:

growing social polarization, with the concentration of global resources increasingly diminished; the reshaping of the capitalism-work relationship, with high levels of unemployment, the over-exploitation of workers and the expansion of unsalaried jobs; the control of public authorities by intergovernmental organizations... whose decisions are imposed even though they have not been democratically elected or designated as representatives; and an ecological crisis that gives rise to a serious depletion of resources and environmental decline, which has enormous human consequences: misery, hunger, and mass migration. (p. 405)

Competition, standardization, privatization, and an eroding commitment to the public sphere formed blueprints for social programs, including schools. As Hursh 
(2005) put it, neoliberal and conservative policy-makers converted education from a public good "into a market" (p. 618).

So the shift my Mexican American graduate student made from social movements for racial justice to standards-based school reform signaled a much larger shift. Neoliberalism, now a global paradigm driving economic and social restructuring, had begun to press schools away from democracy for diverse publics and toward competition and privatization for personal gain.

\section{Neoliberal Multicultural Education?}

Recently, in different contexts for different purposes, I have been asked to comment on three somewhat different teacher evaluation systems. All three were part of wider efforts to align the work of teachers with state curriculum standards and tests, while incorporating multicultural education or culturally responsive teaching to ensure that teachers teach their diverse students more effectively. My reaction to all three was similar. First, the system they were part of had worked to displace the social movements of the 1960s and 1970s. Standards-based curricula include only fragments of knowledge produced by historically marginalized peoples, and the system of ensuring its mastery through testing was not designed primarily by or for those who had been marginalized (although arguably that system was better than outright neglect). Second, diversity had been added into the teacher evaluation systems, rather than forming a basis for them. As a result, responding to diversity was one among many things teachers would be expected to do. Teachers were working in contexts in which knowledge about multiple forms of diversities had become widely available, while their work had become more prescribed, more boxed in. This additive approach to teacher evaluation narrowed multicultural teacher preparation (or teacher professional development) from helping teachers situate schooling within the context of a long history of struggles contesting intersecting forms of institutionalized oppression, to teaching them specific strategies to add to their repertoire.

Such teacher evaluation systems illustrate cooptation under neoliberalism, redefining multicultural education to mean adapting how one teaches, but not necessarily what one teaches or for what purposes. In a system driven by standardized curricula and tests, for example, culturally responsive pedagogy, which Gay (2010) defines as teaching "to and through [students'] personal and cultural strengths, their intellectual capabilities, and their prior accomplishments" (p. 26), is reduced to steps to follow; consideration of culture and curriculum is reduced to cultural celebration as an extracurricular activity (Sleeter, 2012).

Neoliberal multiculturalism desires "a 'soft,' palatable approach to community building that is less discomforting for white people" than multicuturalism focused directly on challenging racism (Case \& Ngo, 2017). Kymlicka (2013) explained that "the first wave of neoliberals in the United States, United Kingdom, Canada, and Australia were uniformly critical of multiculturalism, which they 
viewed as a prime example of unjustified intervention in the market in response to 'special interests'” (p. 107). But because of successes of minoritized groups during the 1970s and 1980s, multiculturalism not only survived neoliberal and reactionary onslaughts, but in some cases it expanded.

So, some neoliberal projects began to incorporate multiculturalism (or "diversity"). Kymlicka offers the example of the World Bank's requirement that countries respect Indigenous rights in order to qualify for loans. Stein (2014) offers additional examples, such as the World Bank's focus on reducing global poverty using means such as reducing debt owed by the poorest countries. The World Bank still operates as a tool of neoliberalism but has softened its image in certain respects. Similarly many businesses, while organized around privatization, profit, and market competition, have expanded their understanding of markets to include more diverse peoples, and as a result view hiring a diverse workforce as an asset to enhancing market competitiveness and profitability. As Kymlicka put it, "The goal of neoliberal multiculturalism is not a tolerant national citizen who is concerned for the disadvantaged in her own society but a cosmopolitan market actor who can compete effectively across state boundaries" (p. 111). Rather than challenging structural inequality, the focus of neoliberal multiculturalism is to manage diversity in a competitive and highly unequal society.

Consider, for example, multicultural education as a tool for incorporating immigrants. While many factors such as economic necessity, environmental deprivation, violence, and war prompt people to move both voluntarily and involuntarily, economic restructuring under neoliberalism has accelerated the global movement of peoples. According to the International Organization for Migration (2017), "In 2015, the number of international migrants worldwide people residing in a country other than their country of birth - was the highest ever recorded" (para. 3). Schools in nations with high intakes of immigrants find themselves challenged. Multicultural education in such contexts is often taken up as a form of remediation and assimilation of new immigrants (Aguado-Odina et al., 2017), and as a way to build "toleration" between immigrants and native-born students. In Taiwan, for example, Liu and Lin (2011) report great interest in multicultural education, but mainly for the purpose of recognizing differences and reducing prejudice. In such cases, multicultural education is less about challenging who has the power to define issues and solutions, and more about managing an influx of diversity.

Dunn (2017) analyzed "discourse in which those who seek to advance neoliberal educational reform use the language of justice and equity in their attempts to reshape public education as a profit centre rather than a public good" (p. 360). An example she offers is the program Teach for All, a global expansion of U.S.-based Teach for America that places college graduates into high-needs classrooms as teachers for a minimum of two years, supported by a short professional training program. Dunn points out that multicultural rhetoric in the program, such as "educational opportunity" and "learning from each other" (p. 366), masks its neoliberal underpinnings. Because of cooptation such as this, Diniz (2017) recommends not using terms such as multicultural education that no longer 
carry a clear meaning, but instead using those that explicitly name what is being addressed, such as anti-sexism, anti-racism, and anti-homophobia.

New teachers today who grew up and were educated within a neoliberal context often have no memory of where multicultural education came from. As a teacher educator, to counteract this problem, I connected my prospective teachers with marginalized grassroots communities in order to raise their consciousness of ongoing struggles for justice and implications for teaching. Similarly, U.S. teacher educators Katsarou, Picower, and Stovall (2010) describe projects in their teacher education programs in New York and Chicago that engage teacher candidates with members of the marginalized communities in which schools are located so they can develop empathy, learn to see strengths of students and their communities, recognize how structures of racism and class impact on communities, and view classrooms as spaces to address community concerns. This kind of consciousness-building connects teacher candidates not just with teaching strategies, but with the deeper rationale and need for multicultural education.

\section{Countermovements}

Kymlicka (2013) points out that neoliberal reforms do not always have their intended consequences, for a variety of reasons. Neoliberal reforms that do not benefit minoritized communities fail to extinguish these communities' prior demands and commitments. In some cases, minoritized communities add aspects of neoliberalism to their own projects on their own terms, such as the Māori in New Zealand setting up their own businesses to deliver services to Māori rather than depending on non-Māori businesses and service providers.

In reaction to the general failure of neoliberal reforms in communities of color, the United States is currently experiencing a vibrant countermovement in the form of ethnic studies at the elementary and secondary levels. While multicultural education and ethnic studies are closely related and in some cases indistinguishable, ethnic studies teachers explicitly reject the whitewashing of neoliberal multicultural education by deliberately centering race and racism, and by embracing a vision for sustaining the cultures, histories, and knowledges of marginalized communities, reflected in the term "culturally sustaining pedagogy." Alim and Paris (2017) explain:

[Culturally sustaining pedagogy] asks us to reimagine schools as sites where diverse, heterogeneous practices are not only valued but sustained. In fundamentally reimagining the purpose of education, CSP demands a critical, emancipatory vision of schooling that reframes the object of critique from our children to oppressive systems. (p. 3)

In 2005, while participating in the summer Institute for Transformation held by the Mexican American/Raza Studies Department of Tucson, Arizona, I learned about the first school-district-wide program designed from the perspective and 
knowledge of a historically marginalized group. Much of the program was rooted in Mexican American/Chicano/a studies as well as Indigenous Mexica knowledge (Nahui Ollin), used to counter the damaging effects of the colonizing curriculum and pedagogy that the Mexican American students had been experiencing (Gonzalez, in press). In some high schools, the Social Justice Education Project offered (a) a curriculum that was culturally and historically relevant to the students, focused on social justice issues, and aligned with state standards but designed through Chicano intellectual knowledge; (b) a critical pedagogy in which students developed critical thinking and critical consciousness, partially through a community-based action research project; and (c) authentic caring for students as intellectual and full human beings (Cammarota \& Romero, 2009). Mexican American/Raza Studies produced a very strong, positive impact on the students, greatly increasing their graduation rates and test scores (Cabrera et al., 2014), and enabling them to develop a sense of power, self-love, and self-efficacy.

However, because of its critical activist focus, White politicians who regarded readings by authors such as Paulo Freire to be seditious and a program centered on the experiences of one marginalized ethnic group to be divisive succeeded in shutting the program down. The teachers turned to the National Education Association (NEA) for support in their fight to save it. The NEA, in an effort to understand how well the research supports ethnic studies programs like this one, hired me to compile a review of research on the impact of such programs on students. For my review, I sought studies reporting data of the impact of "units of study, courses, or programs that are centered on the knowledge and perspectives of an ethnic or racial group, reflecting narratives and points of view rooted in that group's lived experiences and intellectual points of view" (Sleeter, 2011, p. 8). I found consistently positive impacts on the academic achievement of African American, Mexican American, Filipina/o American, and American Indian students and largely positive impacts on the racial attitudes of White students.

My review did not help to save Tucson's program, but outrage against the racist attacks, along with research demonstrating its powerful impact on students (Cabrera et al., 2014), my research review, and an evaluation of another ethnic studies program in San Francisco (Dee \& Penner, 2017) launched what has become a movement for ethnic studies in elementary and secondary schools in the United States. Most of the momentum comes from activism of students and communities of color who see a way forward in efforts to improve education for themselves.

Another ongoing countermovement is the work of Māori educators in New Zealand, who center culture, family (whanau), and language (te reo). Glynn (2015) described and briefly reviewed four such programs that had a positive impact on Māori students. He argued, however, that mainstream New Zealanders were largely unaware of approaches to pedagogy in which Māori students flourish, and it was difficult to introduce these into mainstream schools. He concluded, "Such a pedagogy has the best chance of emerging in institutions which operate totally within a Māori world view, in which it is safe for the language and culture to be nurtured and to flourish" (p. 111). Since most Māori students are being educated 
in mainstream schools, Bishop developed a power-sharing approach in which teachers learn to co-construct classroom processes with their Māori students (see Bishop, Berryman, Cavanagh, \& Teddy, 2009). A large-scale study of the impact of this approach in 33 secondary schools found it to improve the education experiences for Māori students (Meyer et al., 2010).

\section{Looking Ahead}

It is highly likely that nations around the world will continue to experience movements for political rights and recognition as well as immigration or migration involving racially and ethnically diverse families and that these experiences will demand changes in education. Over the past decade, for example, South Korea has experienced a high level of immigration that educators are struggling to figure out how to accommodate. Kim and So's article in this issue, "Understanding the 'Other': Rethinking Multiculturalism in South Korea through Gadamer's Philosophical Hermeneutics" discusses this issue very well. But as with the struggles I glimpsed in South Africa during 1995, the question is less one of which practices can be imported from elsewhere and more one of how dialog and powersharing can be established in historically oppressive contexts, or in contexts involving newcomers whose presence may not be entirely welcomed.

It is also likely that inequality will continue to widen, both globally and within nations. According to Gray (2017) of the World Economic Forum, "The wealth held by the 62 richest people on the planet is estimated at $\$ 1.76$ trillion, a $44 \%$ increase from five years ago. Meanwhile, the 3.5 billion poorest people have seen their wealth shrink by over a trillion dollars, or $41 \%$, in the same period" (para. 2). Under neoliberalism, privatization and the draining of public services are likely to continue, perhaps even accelerate. In the absence of significant intervention, we are also likely to see continued growth of populist movements on the right as people feeling economic anxiety scapegoat immigrants.

Let me offer four recommendations for moving forward. First, as the appeal of multicultural education's classroom strategies for creating bridges between immigrants and native-born students grows, it is important to develop and maintain ideological clarity about what multicultural education is fundamentally for. As I have stressed throughout this essay, multicultural education should rest on dialog in which groups that have the most power learn to listen to and collaborate with those who have less power, particularly around education issues. As a field, multicultural education offers many very useful strategies and conceptual tools. But what educators from dominant groups think are the key issues and best solutions are not necessarily the same as what students, parents, and community members from non-dominant groups think. Some of the most difficult but most necessary work in multicultural education involves helping those who are used to being in charge learn to listen to and take seriously those they have learned to dismiss. 
Second, there needs to be a more systematic program of research on impacts of multicultural education. There are many qualitative case studies showing what multicultural education means to teachers or what it looks like in the classroom (e.g., Ngo, 2010; Weis \& Fine, 2001; Zenkov et al., 2013). In the United States, research on the academic and social impact of ethnic studies on students has been useful for supporting the adoption of ethnic studies at the school district level. Policy-makers pay particular attention to research on academic outcomes, although academic outcomes as measured through tests and other traditional indicators of achievement are not the only impacts of value. Many minoritized communities want their youth to become not only proud of their cultural and language background, but also able to function well within their cultural communities. Alim and Paris (2017) explain that educators often become overly preoccupied with the "White gaze"-which traditional assessments of student learning represent-rather than asking how education might sustain "the lifeways of communities who have been and continue to be damaged and erased through schooling" (p. 1). Research paradigms that capture this concern with sustaining communities, such as Kaupapa Māori research in New Zealand, offer helpful alternatives for framing program impacts.

Third, the field of multicultural education should develop more linkages with the field of bilingual education. In the United States, multicultural education and bilingual education are quite separate, each having its own national organizations, journals, and advocacy organizations. Attempts to link them often subsume one under the other. The state of New Mexico, for example, has in place a Bilingual Multicultural Education Act, operationalized through a Technical Assistance Manual. Both the Act and the Manual, however, focus almost exclusively on bilingual education, giving only cursory attention to concerns of multicultural education. Yet, for many peoples, such as Indigenous communities involved in the recovery of culture and language, culture, language, and power are interwoven and cannot be separated.

Finally, global dialog and organizing for social justice are needed. As Aguado-Odina and her colleagues (2017) argue, we face an emergency that calls for us to mobilize "to collectively create and enable images of education that contribute to a sustained way of building an equitable and fair society" (p. 417). Several prominent international organizations, such as UNESCO, the Office for Democratic Institutions and Human Rights (ODIHR), and the United Nations High Commissioner for Refugees (UNHCR), have convened forums and produced reports for educators based on work in multiple countries. While the substance of these reports is excellent, I see two limitations for their use as an organizing strategy. First, the forums and reports have involved individuals from diverse countries, but not organizations themselves, such as the National Association for Multicultural Education, the International Association for Intercultural Education, the Korean Association for Multicultural Education, or the Pacific Circle Consortium. Convening individuals rather than organizations limits their ability to leverage broad power. Second, terminology as used in different parts of the world can be barriers to collaboration. For example, UNESCO's Guidelines on Intercultural Education (2006) explain: 
Multicultural education uses learning about other cultures in order to produce acceptance, or at least tolerance, of these cultures. Intercultural Education aims to go beyond passive coexistence, to achieve a developing and sustainable way of living together in multicultural societies through the creation of understanding of, respect for and dialogue between the different cultural groups. (p. 18)

While the document's elaboration of intercultural education is fully consistent with multicultural education as understood in the United States, its dismissal of multicultural education alienates a large potential audience and collaborator.

It is fitting that I conclude this essay written for IJMEs anniversary issue by acknowledging the International Journal of Multicultural Education as a highly important venue for global dialog and global organizing. As an international, openaccess journal, IJME offers a global platform for sharing insights and experiences, and for thinking through shared concerns and issues that respect differences while promoting a common sense of justice. Strengthening such global dialog is our work for the foreseeable future.

\section{References}

Aguado-Odina,T., Mata-Benito, P., \& Gil-Jaurena, I. (2017). Mobilizing intercultural education for equity and social justice. Time to react against the intolerable: A proposal from Spain. Intercultural Education 28(4), 408423.

Alim, H. S., \& Paris, D. (2017). What is culturally sustaining pedagogy and why does it matter? In D. Paris \& H. S. Alim (Eds.), Culturally sustaining pedagogies (pp.1-21). New York, NY: Teachers College Press.

Au, K. H., \& Jordan, C. (1981). Teaching reading to Hawaiian children: Finding a culturally appropriate solution. In H. Trueba, G. P. Guthrie, \& K. H. Au (Eds.), Culture in the bilingual classroom: Studies in classroom ethnography (pp. 139-152). Rowley, MA: Newbury House.

Banks, J. A. (1996). Multicultural education, transformative knowledge, and action. New York, NY: Teachers College Press.

Bishop, R., Berryman, M., Cavanagh, T. \& Teddy, L. (2009). Te Kotahitanga: Addressing educational disparities facing Māori students in New Zealand. Teaching and Teacher Education, 25, 734-742.

Cabrera, N. L., Milem, J. F., Jaquette, O., \& Marx, R. W. (2014). Missing the (student achievement) forest for all the (political) trees: Empiricism and the Mexican American student controversy in Tucson. American Educational Research Journal, 51(6), 1084-1118.

Cammarota, J., \& Romero, A. (2009). The Social Justice Education Project: A critically compassionate intellectualism for Chicana/o students. In W. Ayers, 
T. Quinn, \& D. Stovall (Eds.), Handbook for social justice education (pp. 465-476). New York, NY: Routledge.

Case, A., \& Ngo, B. (2017). "Do we have to call it that?" The response of neoliberal multiculturalism to college antiracism efforts. Multicultural Perspectives, 19(4), 215-222.

Commission on Multicultural Education. (1973). No one model American: A statement on multicultural education. Washington, DC: American Association of Colleges of Teacher Education.

Dee, T., \& Penner, E. (2017). The causal effects of cultural relevance: Evidence from an ethnic studies curriculum. American Educational Research Journal, 54(1), 127-166.

Dei, G. J. S. (1993). The challenges of anti-racist education in Canada. Canadian Ethnic Studies, 45(2), 36-51.

Diniz, J. (2017). A construção da identidade de educadoras/es militantes e suas implicações para a formação de professoras/es para a transformação social. [The construction of the identity of activist educators and implications for the formation of teachers for social transformation].Paper presented at the I Seminario Internacional en Educación con Justicia Social, Universidad Católica del Maule, Talca, Chile.

Dunn, A. H. (2017). Refusing to be coopted: Revolutionary multicultural education amidst global neoliberalism. Intercultural Education, 28(4), 356-372.

Freire, P. (1972). Education: Domestication or liberation? Prospects, 2(2), 173181.

Gay, G. (1983). Multiethnic education: Historical developments and future prospects. The Phi Delta Kappan, 64(8), 560-563.

Gay, G. (1995). Bridging multicultural theory and practice. Multicultural Education, 3(1), 4-9.

Gay, G. (2010). Culturally responsive teaching: Theory, research and practice (2nd ed.). New York, NY: Teachers College Press.

Gonzalez, M. (In press). Regeneration/transformation - Cultivating self-love through Tezcatlipoca. In M. Zavala, R. T. Cuauhtin, W. Au, \& C. Sleeter (Eds.), Rethinking ethnic studies. Milwaukee, WI: Rethinking Schools, Ltd.

Glynn, T. (2015). Bicultural challenges for educational professionals in Aotearoa. Waikato Journal of Education, 20, 103-113.

Gray, A. (2017). Three charts that explain global inequality. World Economic Forum. Retrieved from https://www.weforum.org/agenda/2016/01/3-chartsthat-explain-global-inequality/

Hacker, J. S., \& Pierson, P. (2010). Winner-take-all politics. New York, NY: Simon \& Schuster Paperbacks. 
Harvey, D. (2005). A brief history of neoliberalism. New York, NY: Oxford University Press.

Hursh, D. (2005). The growth of high-stakes testing in the USA: Accountability, markets, and the decline in educational equality. British Educational Research Journal, 31(5), 605-62.

International Organization for Migration (2017). Global migration trends factsheet. Retrieved from http://gmdac.iom.int/global-migration-trends-factsheet.

Katsarou, E., Picower, B., \& Stovall, D. (2010). Acts of solidarity: Developing urban social justice educators in the struggle for quality public education. Teacher Education Quarterly, 37(3), 137-153.

Kymlicka, W. (2013). Neoliberal multiculturalism? In P. A. Hall \& M. Lamont (Eds.), Social resilience in the neoliberal era (pp. 99-124). Cambridge, UK: Cambridge University Press.

Liu, M., \& Lin, T. B. (2011). The development of multicultural education in Taiwan: Overview and reflection. In C. A. Grant \& A. Portera (Eds.), Intercultural and multicultural education (pp. 157-76). New York, NY: Routledge.

Linton, S. (1998). Claiming disability: Knowledge and identity. New York: New York University Press.

MacGillivray, I. K. (2000). Educational equity for gay, lesbian, bisexual, transgendered, and queer/questioning students. Education and Urban Society, 32(3), 303-323.

McCarty, T. L. (1993). Language, literacy, and the image of the child in American Indian classrooms. Language Arts, 70(3), 182-192.

Meyer, L.H., Penetito, W., Hynds, A., Savage, C., Hindle, R., \& Sleeter, C.E. (2010). Evaluation of TeKotahitanga: 2004-2008. Wellington: New Zealand Ministry of Education. Retrieved from http://www.educationcounts.govt.nz/ 78910

Mayer, J. (2016). Dark money: The hidden history of the billionaires behind the rise of the radical right. New York: Doubleday.

National Commission on Excellence in Education. (1983). A nation at risk: The imperative for educational reform. Washington, DC: U.S. Department of Education.

Neilsen, D. (2011). Making history beyond neoliberalism. New Zealand Sociology, 26(2), 66-76.

Ngo, B. (2010). Doing "diversity" at Dynamic High: Problems and possibilities of multicultural education in practice. Education and Urban Society, 42(4), 473-495.

Ratteray, J. D. (1990). African-American achievement: A research agenda emphasizing independent schools. In K. Lomotey (Ed.), Going to school: 
The African-American experience (pp. 197-208). Albany, NY: State University of New York Press.

Sleeter, C. E. (1995). An analysis of the critiques of multicultural education. In J. A. Banks \& C. M. Banks (Eds.), Handbook of research on multicultural education (pp. 81-94). New York, NY: Macmillan.

Sleeter, C. E. (2011). The academic and social value of ethnic studies. Washington, D.C.: National Education Association.

Sleeter, C. E. (2012). Confronting the marginalization of culturally responsive pedagogy. Urban Education, 47(3), 562-584.

Sleeter, C. E., \& Grant, C. A. (2009). Making choices for multicultural education: Five approaches to race, class and gender (6th ed.). New York: Wiley.

Sleeter, C., Hughes, B., Meador, E., Whang, P., Rogers, L., Blackwell, K., Laughlin, P. \& Peralta-Nash, C. (2005). Working an academically rigorous, multicultural program. Equity \& Excellence in Education, 38(4), 290-299.

Stein, H. (2014, July 28). The World Bank and neoliberalism: Continuity and discontinuity in the making of an agenda. The World Financial Review. Retrieved from http://www.worldfinancialreview.com/?p=2580

Torres, C. A. (2002). The state, privatisation, and educational policy: A critique of neoliberalism in Latin America and some ethical and political implications. Comparative Education, 38(4), 365-385.

Troyna, B. (1987). Beyond multiculturalism: Towards the enactment of anti-racist education in policy, provision and pedagogy. Oxford Review of Education 13(3), 307-20.

UNESCO (2006). UNESCO guidelines on intercultural education. Paris, France: UNESCO.

Weis, L., \& Fine, M. (2001). Extraordinary conversations in public schools. Qualitative Studies in Education, 14(4), 497-523.

Zenkov, K., Pellegrino, A., Harmon, J., Ewaida, M., Bell, A., Lynch, M., \& Sell, C. (2013). Picturing culturally relevant literacy practices: Using photography to see how literacy pedagogies matter to urban youth. International Journal of Multicultural Education, 15(2), 1-20.

\section{Author Contact}

Christine Sleeter: csleeter@gmail.com

CSU Monterey Bay, 100 Campus Center, Seaside, CA 93955 